ISSN: 2146-3042

DOI: $10.25095 /$ mufad.536077

\title{
Enflasyon Ve Dış Ticaret Açığının Borsa Endeks Getirileri Üzerindeki Etkisi: Borsa İstanbul 100 Endeksinde Bir Uygulama
}

Gamze ŞEKEROĞLU*

Okyay UÇAN**

Melek ACAR ${ }^{* * *}$

\begin{abstract}
$\ddot{O Z Z E T}$
Borsa İstanbul pay piyasası açısından temel endeks niteliğinde olan Borsa İstanbul 100(BİST 100) Endeksi, piyasa değeri ve ișlem hacmi en yüksek olan paylardan oluştuğundan, Borsa İstanbul'un durumunu en iyi yansitan endeks olma özelliğini taşımaktadır. Bu endeksi etkileyen çeșitli makroekonomik değișkenler söz konusudur. Çalıșmada, söz konusu makroekonomik değişkenlerden enflasyon ve dış ticaret açığının 2004:M1 - 2017:M12 dönemlerinde BiST 100 Endeksiyle olan ilişkisi, Johansen ve Gregory\&Hansen eşbütünleşme testleri kullanılarak incelenmiştir. Eşbütünleşme testleri yapılmadan önce, birim kök içeren her değişkenin aynı seviyede durağan olmaları gerektiği varsayımı altında, hem geleneksel birim kök testi olan ADF (Augmented Dickey Fuller), hem de yapısal kirlmaları göz önüne alan LS (Lee \&Strazicich) birim kök testleri yapılmıștır. Serinin durağan olmayan bazı değișkenleri de durağan hale getirildikten sonra VAR (Vector Autoregressive)modeli uygulanmıştır. Yapılan analizler sonucunda, değişkenler arasında uzun dönemli bir iliş̧kinin varlığı iki farklı eșbütünleşme testi ile desteklenmiștir. Ayrıca, BIST 100 Endeksinde kısa dönemde meydana gelen oynaklıklar, 14 aylık periyotla uzun dönem dengesine ulaşmaktadır.

Anahtar Kelimeler: Johansen Eşbütünleşme Testi, Gregory\&Hansen Eşbütünleşme Testi, BiST 100 Endeksi, Enflasyon, Dış Ticaret Açı̆̆ı, VAR Modeli.
\end{abstract}

JEL Sinıflandırması: E31, F65.

The Effect Of Inflation And Foreign Trade Deficit On The Stock Exchange Revenue: An Application Of BIST 100 Index

ABSTRACT

Borsa Istanbul 100 (BIST 100) Index, which is the main index in terms of Borsa Istanbul stock market, is the index that best reflects the situation of Borsa Istanbul as it consists of the stocks with the highest market value and transaction volume. There are various macroeconomic variables affecting this index. In the study, the relationship between inflation and foreign trade deficit, which are macroeconomic variables, and the BIST 100 Index during the period of 2004: M1 - 2017: M12 was examined using Johansen and Gregory \& Hansen cointegration tests. Before doing cointegration tests, both ADF (Augmented Dickey Fuller) which is the conventional unit root test and the LS (Lee \& Strazicich) unit root tests were performed under the assumption that each variable containing unit roots should be stationary at the same level. VAR (Vector Autoregressive) model was applied after some non-stationary variables of the series were stationary state. As a result of the analyses, the existence of a long-run relationship between the variables was supported by two different cointegration tests. In addition, short-term volatility in the BIST 100 Index reaches a long-run equilibrium over a period of 14 months.

Keywords:

Jel Classification: E31, F65.

Makale Gönderim Tarihi: 25.04.2018

Makale Kabul Tarihi: 25.07.2018

\footnotetext{
* Arş. Gör., Selçuk Üniversitesi, İktisadi ve İdari Bilimler Fakültesi, gmztrmn@ gmail.com.

** Doç. Dr., Niğde Ömer Halisdemir Üniversitesi, İktisadi ve İdari Bilimler Fakültesi, okyayucan@ ohu.edu.tr, ORCID ID: 0000-0001-5221-4682

*** Prof. Dr., Selçuk Üniversitesi, İktisadi ve İdari Bilimler Fakültesi, melekacar@yahoo.com.
} 


\section{GíRiş}

Sermaye piyasalarının hem bireysel hem de kurumsal aktörleri açısından pay fiyatlarındaki değişmeleri öngörebilmek oldukça önemlidir. Çünkü pay fiyatlarındaki volatilitenin tahmin edilmesiyle, yatırımcılar için uygun portföylerin oluşturulması ve sermayenin bütçelenmesi mümkün olmaktadır. Fiyat hareketlerini etkileyen çeşitli faktörler göz önünde bulundurularak değerlendirmeler yapmak, yatırımcıların yatırım kararlarını etkilediği gibi, sermaye piyasalarının gelişmesine de olumlu katkılar sağlamaktadır. Literatürde bu konuda yapılan çalışmalar neticesinde bu faktörlerin çoğu bilinmekte, ancak hangi faktörün hangi dönemde daha fazla etki göstereceği tam olarak belirlenemeyebilmektedir.Bu faktörler, yatırımcı davranışlarına göre psikolojik ve piyasa koşullarına göre ise ekonomik olarak sinıflandırılmaktadır (Özer vd., 2011: 164; Mutan ve Çanakç1, 2007: 31). Mikro ve makro boyutlarıyla incelenen ekonomik faktörler, yaklaşık yarım asırdır ekonomi ve finans kesimlerince incelenmektedir.

Enflasyon, döviz kuru, faiz oranları, dış ticaret dengesi, altın ve petrol fiyatları gibi makroekonomik faktörler, pay fiyatlarıyla farklı derecede ve yönde ilişki içerisinde olabilmektedir. Ayrıca, ekonomik faktörlerdeki değişimlerin nedenleri çok farklı olmakla beraber, makroekonomik açıdan meydana gelen değişiklikler, bir ekonomide faaliyet gösteren bütün şirketleri etkilemektedir. Bu sebeple, payları etkileyen faktörleri ve bu faktörlerin pay piyasasını ne ölçüde etkilediklerini anlayabilmek oldukça önemlidir (Umutlu vd., 2010: 8).

Her çalışmada kullanılan makroekonomik değişkenler, çalışmaların amacına göre farklılık göstermektedir. Genellikle dört gruba ayrılarak incelenen makroekonomik değişkenlerin ilk grubu, istihdam düzeyi ve sanayi üretim endeksi gibi genel ekonomik koşullardan oluşmaktadır. İkinci grup, faiz oranı ve para politikası ile ilgili değişkenleri içermektedir. Üçüncü grup değişkenler, enflasyon oranı, dış ticaret rakamları ya da petrol fiyatları gibi önemli varlıkların fiyatlarını kapsamaktadır. Son grup ise, döviz kuru ve doğrudan yabancı yatırımlar gibi uluslararası faaliyetleri içeren değişkenler üzerine yoğunlaşmaktadır. Bazı çalışmalar genel olarak makroekonomik faktörleri incelemekte ve birçok değişkeni analize konu etmekteyken, bazı çalışmalar belirli değişkenlere veya değişken gruplarına odaklanmaktadırlar (Tangjitprom, 2012: 107).

İlk gruptaki makroekonomik değişkenlerden sanayi üretim endeksinde meydana gelen artışlar, pay senedi yatırımcıları tarafından olumlu olarak algılanmaktadır. Çünkü endeksteki yükseliş, nakit akışlarıyla ilgili gelecekteki beklentilerin olumlu olmasına ve firmaların mali tablolarındaki karlarının artmasına yol açacağı için pay senedi fiyatlarını da artıracaktır (Kartal, 2011: 54).

İkinci grup değişkenlerden olan faiz oranı ile pay senedi fiyatları arasındaki ilişkinin negatif olduğu görüşü, konuyla ilgili yapılmış çalışmaların çoğunda kabul görmüştür. Yatırımcılar açısından tahvil gibi faize dayalı araçlar, pay senetlerinin önemli bir alternatifi olduğundan, faiz oranlarında meydana gelen bir değişiklik, pay senedi piyasalarına olan talebi etkileyerek pay senedi getirilerini şekillendirmektedir (Uzun ve Güngör, 2017: 6). Bir ekonomide dönen toplam para miktarı olarak tanımlanan para arzındaki değişiklikler ise, toplam talebin hacmini belirlemektedir. Toplam talep artışından kaynaklı olarak şirket kazançları yükselmekte, dolayısıyla şirketlerin hisse senetlerine olan talep artış 
göstermektedir. Kısacası, para arzındaki artış neticesinde, pay senetlerinin değerinde ve fiyatında yükselme meydana gelmektedir (Zengin, 2009: 73).

Üçüncü gruptaki değişkenlerden enflasyon ile pay getirileri arasındaki ilişkiyle ilgili olarak tam bir fikir birliği söz konusu değildir. Aradaki ilişkinin pozitif, negatif, hatta bağımsız olduğunu ileri süren çalışmalar bulunmaktadır (Ulaş, 2010: 76). Örneğin, Fisher'ın (1930) faiz teorisine göre, enflasyon ve pay getirileri arasındaki ilişkinin yönü pozitiftir. Günümüzde Fisher Etkisi olarak bilinen teoride, nominal faiz oranlarının beklenen enflasyon rakamlarını etkileyebilecek tüm bilgileri içereceği kabul edilmektedir.Pay senedi fiyatlarının enflasyona karşı dirençli olabilmesi için ise, artan enflasyon rakamlarıyla birlikte pay senedi fiyatlarının artış göstermesi gerekmektedir.Grubun diğer değişkeni olan dış ticaret açığ 1 , ülke ekonomisi üzerinde geniş kapsamlı etkilere sahiptir. Esasen ekonomik ilişkilerde önemli bir faktör olduğu ileri sürülen dış ticaret dengesi ile pay getirileri arasındaki ilişki, literatürde büyük ölçüde ihmal edilmiştir (Eren, 2014: 13-14; Y1lmaz vd., 2004: 6).

Son gruptaki döviz kuru değişkeniyle ilgili olarak iki farklı durum söz konusudur. İlk duruma göre, çok uluslu şirketler başta olmak üzere tüm firmaların pay senedi fiyatları döviz kuru değişimlerinden olumlu olarak etkilenmektedir. Çünkü, döviz kurlarındaki değişiklik, firmaların yabancı yatırımlarını, yurtdışı satışlarını ve ithal ürünlerini etkilemektedir. Dolayısıyla, döviz kurlarında meydana gelen artışlar, firmanın içinde bulunduğu ülkedeki ürünlerin, yurtdışı piyasalarda daha rekabetçi durumda olmasını sağlayarak ihracatın canlanmasına sebep olmaktadır. İhracatı yüksek bir firmanın da pay senedi fiyatları artış göstermektedir (Aggarwal, 1981: 9-10). Diğer durumda ise, döviz kurlarında meydana gelen düşüşler, ulusal para birimine olan talebi ve faiz oranlarını artırmaktadır. Yabancı sermayenin ülkeye girmesiyle birlikte, ulusal para birimi cinsinden yatırımlar ve dolayısıyla pay senedi fiyatları da artı̧̧ göstermektedir (Frankel, 1983: 93-95).

Tüm bu faktörler göz önünde bulundurularak, pay senedi yatırımcılarının beklentileri, fiyatları doğru tahmin ederek düşük bir risk seviyesinde belli bir getiri elde etmektir. Bu açıdan yapılması gereken, beklentiye yön veren ve pay senedi fiyatlarını etkilediği düşünülen makroekonomik faktörlerin analiz edilmesidir (Yeşildağ, 2016: 52). Çünkü, makroekonomik faktörlerin gelecekteki eğilimlerinin doğru tahmin edilmesi, yatırımcılar için pay senedi getirilerinin yönünü görmeye yardımcı olacaktır (Ozlen ve Ergun, 2012: 315).

$\mathrm{Bu}$ çalışmadaki makroekonomik değişkenler; enflasyon ve diş ticaret açığı olarak belirlenmiştir. Bu bağlamda çalışmanın amacı, BİST 100 Endeksi ile enflasyon ve dış ticaret açığı arasındaki ilişkiyi tespit etmektir.Bunun için öncelikle literatürde konuyla ilgili yapılmış çalışmalar incelenmiş, veri seti ve yöntem hakkında bilgi verilmiş, son olarak Johansen ve Gregory\&Hansen eşbütünleşme testleri kullanılarak değişkenler arasındaki ilişki tespit edilmiş ve ulaşılan sonuçlar değerlendirilmiştir.

\section{LITERATÜR}

Yıllar boyunca pek çok ülkenin pay fiyatlarında beklenmedik volatiliteler görülmüş ve çok sayıda araştırmacı bunların makroekonomik faktörlerden kaynaklanabileceğini ifade etmiştir. Bunun üzerine para arzı, enflasyon, faiz oranı, sanayi üretimi, gayri safi milli hasıla, dış ticaret dengesi, döviz kuru ve petrol fiyatları gibi çeşitli makroekonomik değişkenlerle pay fiyatları arasındaki ilişki incelenmiştir. Bu konuda yapılan çalışmalardan bazıları birbirlerini 
desteklerken, bazıları da birbirleriyle çelişen sonuçları beraberinde getirmiştir. Elde edilen bulgular, ülkeden ülkeye farklılık gösterdiği gibi, aynı ülkede yapılan farklı çalışmalarda da farklı neticelere ulaşılmıştır (Özer vd., 2011: 164). Aşağıda konuyla ilgili yapıllmış bazı çalışmalara yer verilmiştir.

Kwon ve Shin (1999), Kore Borsası'nda 1980 Haziran- 1992 Aralık dönemi için pay getirileri ile bazı makroekonomik değişkenler arasındaki ilişkiyi eşbütünleşme ve nedensellik testleriyle incelemiştir. Sonuçta sanayi üretim endeksi, döviz kuru, diş ticaret dengesi ve para arzı değişkenlerinin pay getirileriyle eşbütünleşik ve uzun dönemli bir ilişkiye sahip olduğu tespit edilmiştir. Ayrıca çalışma neticesinde Kore Borsası'nın uluslar arası ticari faaliyetler açısından oldukça hassas olduğu ve özellikle enflasyon ve faiz oranlarından fazlaca etkilendiği vurgulanmıştır.

Khill ve Lee (2000), Amerika ve 10 Pasifik ülkesinde (Avustralya, Hong Kong, Endonezya, Japonya, Kore, Malezya, Filipinler, Singapur, Tayvan ve Tayland) 1970-1997 yılları arasındaki pay getirileri ile enflasyon arasındaki ilişkiyi regresyon ve korelasyon testleriyle incelemiştir. Veri olarak nominal pay getirileri, tüketici fiyat endeksini (TÜFE), enflasyon ve reel pay getirilerinin kullanıldığ ülkelerde pay getirileri ile enflasyon arasında negatif yönlü bir ilişkinin varlığı tespit edilmiştir.

Choundhry (2001), yüksek enflasyona sahip olan Arjantin, Şili, Meksika ve Venezüella'daki pay getirileri ile enflasyon oranları arasındaki ilişkiyi incelemiştir. ARIMA modeliyle bir yıl için yapılan analiz sonucunda, her ülke için pay getirileri ile enflasyon oranı arasında pozitif bir ilişki bulunmuştur.

Engsted ve Tanggaard'in (2002) çalışmaları, Danimarka ve Amerika borsalarındaki beklenen pay getirileri ile beklenen enflasyon arasındaki ilişkiyi belirlemeye yöneliktir. Hem uzun hem de kısa dönemdeki etkinin incelendiği çalışmada, VAR modeli uygulanmıştır. Amerika Borsası için 1926-1997 dönemleri, Danimarka borsası için de 1922-1996 dönemleri analiz edilmiştir. Sonuçta, Danimarka için beklenen enflasyon ile beklenen pay getirileri arasında kısa dönemde ilişki görülmezken, uzun dönemde ters yönlü ilişki bulunmuştur. Amerika için ise, enflasyon ve beklenen getiri arasında uzun dönemde pozitif yönlü fakat oldukça zayıf bir ilişki olduğu ortaya konmuştur.

Karamustafa ve Karakaya (2004), Johansen-Juselius Koentegrasyon Testi (JJ) aracılığıyla oluşturulan Hata Düzeltme Modeli ile enflasyonun 1995/Ocak - 2003/Haziran dönemindeki borsa performansı üzerindeki etkisini incelemiştir. Çalışmada borsa performansı göstergesi olarak işlem hacmi, piyasa değeri, İMKB 100 Endeksi, işlem miktarı, sözleşme sayısı ve işlem gören şirket sayısı değişkenleri alınırken, enflasyon göstergesi olarak ise, TÜFE değerlerinin aylık verileri kullanılmıştır. Ulaşılan sonuçlara göre; literatürde uzun dönemdeki ters yönlü anlamlı ilişkinin Türk pay piyasası açısından da kısmen geçerli olduğu görülmüştür. Ancak, kısa dönem ilişkiler ele alındığında, enflasyonun işlem hacmi ile pozitif yönlü ilişkisinin olduğu, işlem miktarı üzerinde ise, herhangi bir etkisinin olmadığ görülmüştür. İşlem gören şirket sayısı açısından ise, uzun ve kısa dönemde enflasyon trendinin etkili olmadığı çalışmadan elde edilen diğer bir sonuçtur. 
Yılmaz vd. (2004), 1990: 01-2003: 12 dönemi için İMKB 100 Endeksi ile TÜFE, para arzı, faiz oranı, döviz kuru, dış ticaret dengesi ve sanayi üretim endeksi değişkenleri arasındaki ilişkiyi en küçük kareler yöntemi, Johansen-Juselius eşbütünleşme testi, Granger Nedensellik testi ve VEC modeli ile incelemiştir. En küçük kareler tahminlerine göre; döviz kuru, TÜFE ve para arzı değişkenlerindeki değişimin endeksi pozitif ve anlamlı bir şekilde etkilediği; faiz oranı ve dış ticaret dengesi değişkenlerindeki değişimin ise endeksi negatif ve anlamlı bir şekilde etkilediği belirlenmiştir. Yapılan eşbütünleşme testi sonuçlarına göre; İMKB 100 Endeksi ile TÜFE, faiz oranı ve sanayi üretim endeksi değişkenleri arasında uzun dönemli bir ilişkinin varlığı tespit edilmiştir. Ayrıca, İMKB 100 Endeksi ile döviz kuru ve para arzı değişkenleri arasında çift yönlü, TÜFE ve faiz oranı değişkenleri ile Endeks arasında ise TÜFE ve faiz oranından Endekse doğru tek yönlü bir nedensellik ilişsisi bulunmuştur. Sanayi üretim endeksi ve dış ticaret dengesi değişkenleri ile Endeks arasında ise herhangi bir nedensellik ilişkisi bulunmamıştır.

Ratanapacorn ve Sharma (2007), Amerika'da S\&P 500 Endeksi ile para arz1, sanayi üretim endeksi, hazine bonosu faiz oranı, tahvil faiz oranı, TÜFE ve Japon Yeni/Dolar kuru arasındaki ilişkiyi 1975-1999 dönemleri için incelemiştir. Yapılan analiz sonuçlarına göre; S\&P 500 Endeksi ile uzun vadeli faiz oranları arasında negatif, sanayi üretim endeksi, para arzı, TÜFE, döviz kuru ve kısa vadeli faiz oranları arasında pozitif ilişki tespit edilmiştir. Nedensellik bulgularında ise, S\&P 500 Endeksi ile sanayi üretim endeksi arasında uzun dönemli ve çift yönlü bir ilişki tespit edilmiştir. Ayrıca, analizde kullanılan diğer tüm değişkenlerle de S\&P 500 Endeksi arasında, endekse doğru tek yönlü ilişkilerin varlı̆̆ belirlenmiştir.

Dizdarlar ve Derindere (2008), İMKB 100 Endeksini etkileyen makroekonomik göstergeler üzerine yaptıkları çalışmada cari işlemler hesabı, dış ticaret dengesi, yurtiçi doğrudan yatırımlar, portföy yatırımları, emisyon hacmi, para arzı, sanayi üretim endeksi, dış borç, tüketici fiyat endeksi, altın fiyatları, açık piyasa işlemleri ağırlıklı ortalama faizi, açık piyasa repo ve ters repo işlemleri ve bankalar arası para piyasası verilerini kullanmıştır. Yapılan analizler sonucunda,14 makro ekonomik değişken 2005:12-2007:12 dönemi için analiz edildiğinde, sadece döviz kurunun İMKB 100 endeksi üzerine etkili bir faktör olduğu tespit edilmiştir.

Zügül ve Şahin (2009), Ocak 2004- Aralık 2008 dönemi aylık verilerini kullanarak, İMKB 100 Endeksi ile dolar döviz kuru, M1 para arzı, faiz oranı ve tüketici fiyat endeksi değişkenleri arasında bir ilişki olup olmadığını araştırılmıştır. Verilerin analizi doğrusal regresyon yöntemi ile yapılmıştır. Elde edilen sonuçlara göre; M1 para arzı, döviz kuru ve faiz oranı ile İMKB 100 Endeksi arasında negatif, enflasyon oranıla İMKB 100 Endeksi arasında pozitif yönlü bir ilişki olduğu ortaya çıkmıştır.

Li vd. (2010), İngiltere'deki pay getirileri ile enflasyon arasındaki ilişkiyi inceledikleri çalışmada, FTSE Tüm Endeksindeki 10 sektörün farklı dönemlerini analiz etmişlerdir. ARIMA modelinin kullanıldığı çalışma sonucunda, İngiltere borsasının kısa vadede enflasyona karşı korunmayı başaramadığı, orta vadede ise, daha karmaşık sonuçlara ulaşıldı̆̆ belirtilmiştir. Dolayısıyla, farklı enflasyonist rejimler ve getiriler arasındaki ilişkinin farklı olduğu bulgusu vurgulanmıştır. 
Umutlu vd. (2010), çalışmalarında 2003-2010 yılları arasında İMKB 100 Endeksini etkileyen değişkenlerin, 2008 krizi öncesinde ve sonrasında değişiklik gösterip göstermediğini incelemiş̧lerdir. Araştırma dönemine ait İMKB 100 Endeksi, S\&P 500 Endeksi, üretici fiyat endeksi (ÜFE), TÜFE, TL/USD döviz kuru ve mevduat faiz oranı verileri kullanılmıştır. Sonuçta, İMKB 100 Endeksinin faiz oranı, döviz kuru ve S\&P 500 Endeksiyle açıklanabildiği görülmüştür. Faiz oranı ve döviz kurundaki artışın, İMKB 100 Endeksini negatif yönde; S\&P Endeksindeki artışın ise, pozitif yönde etkilediği bulunmuştur. Ayrıca, nedensellik bulgularına göre; faiz oranı ve döviz kuru ile faiz oranı ve İMKB 100 Endeksi arasında çift yönlü bir ilişki tespit edilmişken, S\&P 500 Endeksinin döviz kurunu etkilemediği görülmüştür.

Özer vd. (2011), Ocak 1996- Aralık 2009 dönemi aylık verilerini kullanarak, İMKB 100 Endeksi ile faiz oranı, para arzı, dış ticaret dengesi, sanayi üretim endeksi, altın fiyatları, döviz kuru ve tüketici fiyat endeksi arasında bir ilişki olup olmadığını tespit etmeyi amaçlamışlardır. Çalışmada yapılan Johansen-Juselius Eşbütünleşme Testi sonucunda; pay fiyatı ile tüketici fiyat indeksi, faiz oranı, para arzı, dış ticaret dengesi ve sanayi üretim endeksi değişkenleri arasında uzun dönemli bir ilişki bulunmuştur. Granger Nedensellik Testi bulgularına göre ise, tüketici fiyat endeksi, dış ticaret dengesi ve faiz oranı değişkenlerinden pay fiyatlarına doğru tek yönlü ve pay fiyatlarından altın fiyatları, para arzı ve sanayi üretim endeksi değişkenlerine doğru tek yönlü ilişkiler tespit edilmiştir. Ayrıca, sanayi üretim endeksi, döviz kuru, TÜFE, para arzı, altın fiyatları değişkenlerindeki değişimin İMKB 100 Endeksini pozitif ve anlamlı bir şekilde etkilediği; faiz oranı ve diş ticaret dengesi değişkenlerindeki değişimin ise, negatif ve anlamlı bir şekilde etkilediği belirlenmiştir.

Oxman (2012), fiyat enflasyonu ve pay getirilerini S\&P 500 Endeksi verileri üzerinden VAR metodu kullanarak incelemiştir. Çalışmadan ulaşılan sonuç, İkinci Dünya Savaşı'ndan sonra fiyat enflasyonu ve pay getirilerinin negatif olarak ilişkilendirilmesinin, çalışmalarda uygulanan modellerin spesifikasyonuna bağlı olduğu şeklindedir. Ayrıca bu çalışma, fiyat enflasyonunun ve pay getirilerinin, kullanılan enflasyonun ölçüsüne bağlı olarak farklı ilişkiler gösterdiğini belirtmektedir.

Ray (2012), Hindistan'daki pay fiyatlarıyla farklı makroekonomik göstergeler arasındaki ilişkiyi, 1990 ve 2010 yılları arasındaki yıllık verileri kullanarak incelemiştir. Araştırmanın çoklu regresyon sonuçları, petrol fiyatı ve altın fiyatının pay fiyatı üzerinde olumsuz bir etkiye sahip olduğunu gösterirken, ticaret dengesi, faiz oranı, döviz rezervleri, gayri safi yurtiçi hasıla, sanayi üretim endeksi ve para arzının pay fiyatını olumlu yönde etkilediğini raporlamaktadır. Ayrıca, pay fiyatı ile döviz rezervi, para arzı, ham petrol fiyatı ve tüm fiyat endeksi arasında iki yönlü nedensellik olduğu tespit edilmiştir.

Ulusan (2014),VAR ve Granger nedensellik analizleri kapsamında BIST getirileri, dış ticaret açıği ve enflasyon arasındaki etkileşimi incelenmiştir. Çalışmanın verileri, Ocak 2006 - Ağustos 2013 aralığında BIST 100 Endeksinin getirileri, dış ticaret büyüme oranları ve enflasyon büyüme oranlarından oluşmaktadır. Yapılan analizler sonucunda, BIST 100 Endeksi getirileri ile hem dış ticaret açığı arasında hem de enflasyon büyüme oranları arasında doğrusal ve anlamlı bir ilişki bulunmuşken, nedensellik açısından BIST 100 Endeksinden enflasyona doğru ve dış ticaret açığına doğru tek yönlü ilişsiler tespit edilmiştir.

Tiwari vd. (2015)'nin pay getirileri ve enflasyon arasındaki ilişkiyi incelediği çalışma, 1961-2012 yıllarını kapsayan uzun bir örnekleme dönemine sahiptir. Çalışmada, Granger 
nedensellik ve sürekli dalgacık dönüşümü metodolojisi kullanılarak Pakistan borsası değerlendirilmiştir. Sonuç olarak, tüketici fiyat endeksine göre uzun dönemde ilişki pozitif iken, üretici fiyat endeksine göre herhangi bir ilişki bulunmamıştır.

Nawaz vd., 2017 yllında Pakistan'da enflasyon ve seçilmiş makroekonomik göstergeler arasındaki korelasyon ve nedenselliği incelemiş̧ir. 1990-2012 yılları için zaman serileri verileri kullanılarak yapılan regresyon analizi sonucunda; para arzı, devlet harcamaları, devlet gelirleri, doğrudan yabancı yatırımlar ve gayri safi yurtiçi hasılanın enflasyon üzerinde olumlu etki yarattığı ancak, faiz oranının olumsuz etkisi olduğu tespit edilmiştir. Ayrıca, para arzının ve ticaret dengesinin seçilen dönemde enflasyona neden olduğu sonucuna ulaşılmıştır.

\section{METODOLOJI}

\subsection{Araștırma Yöntemi ve Veriler}

Bu çalışma, 2004:M1 - 2017:M12 dönemini kapsayan 168 adet aylık veriden oluşmaktadır. Veriler, TCMB veri dağıtım sistemi EVDS, TUIK, Maliye Bakanlı̆ğ 1 ve İş̧ Yatırım'dan alınarak derlenmiştir. Verilerin analizinde Eviews 9.5 ve Rats 9.2 ekonometrik programları kullanılmıştır. Değişkenler; aylık BİST 100 Endeks getirileri (Bist100), aylık enflasyon (Enf) ve aylık dış ticaret açı̆̆ı değişiminden (Dtic) oluşmaktadır. BİST 100 Endeksi, temel pazar endeksi olarak kabul edilmekte ve borsada işlem hacminin büyük bir kısmını kapsamaktadır. Diğer bir değişken olan enflasyon değişkenini karşılamak üzere aylık TÜFE rakamları kullanılmıştır.

2004- 2017 yılları arasında siyasi, ekonomik ve askeri anlamda verilerde oynakliklara neden olabilecek gelişmeler yaşanmıştır. Bu nedenle çalışmada, değiş̧kenler arasındaki uzun dönemli ilişkinin varlığını belirlemek için hem geleneksel Johansen eşbütünleşme testi (Johansen, 1988; Johansen ve Juselius, 1990) hem de yapısal kırılmaları göz önüne alan Gregory\&Hansen eşbütünleşme testi kullanılmıştır. Her iki eşbütünleşme testinin uyumlu olup olmadığ olacaktır. Çalışmanın devamında şayet değişkenler arasında uzun dönemli bir ilişki mevcut ise, ilişkinin kısa vadede nasıl gerçekleştiğinin anlaşılması için Hata Düzeltme Modeli (HDM) uygulanacaktır. HDM sonucuna göre, kısa vadedeki dalgalanmaların uzun vadede ne zaman dengeye yakınsayacağı belirlenecektir.

Analizin ilk aşamasında hem kırıklı hem de geleneksel eşbütünleşme analizi için birim kök içeren her değişkenin aynı seviyede durağan olmaları gerekmektedir. Bu amaçla hem geleneksel birim kök testi olan ADF testi hem de yapısal kırılmaları göz önüne alan LS (Lee \&Strazicich, 2003) birim kök testi yapılacaktır. Daha sonra eşbütünleşme analizinin işleyebilmesi için öncelikle VAR analizi uygulanmalı ve gecikme sayısı belirlenmelidir.

\subsection{Ampirik Analiz Sonuçları}

Değişkenlerin durağanlığını kontrol etmek için kullanılan geleneksel ve yapısal kırılmaları dikkate alan birim kök testi sonuçları Tablo 1'de verilmiştir. 
Tablo 1. Birim Kök Testleri

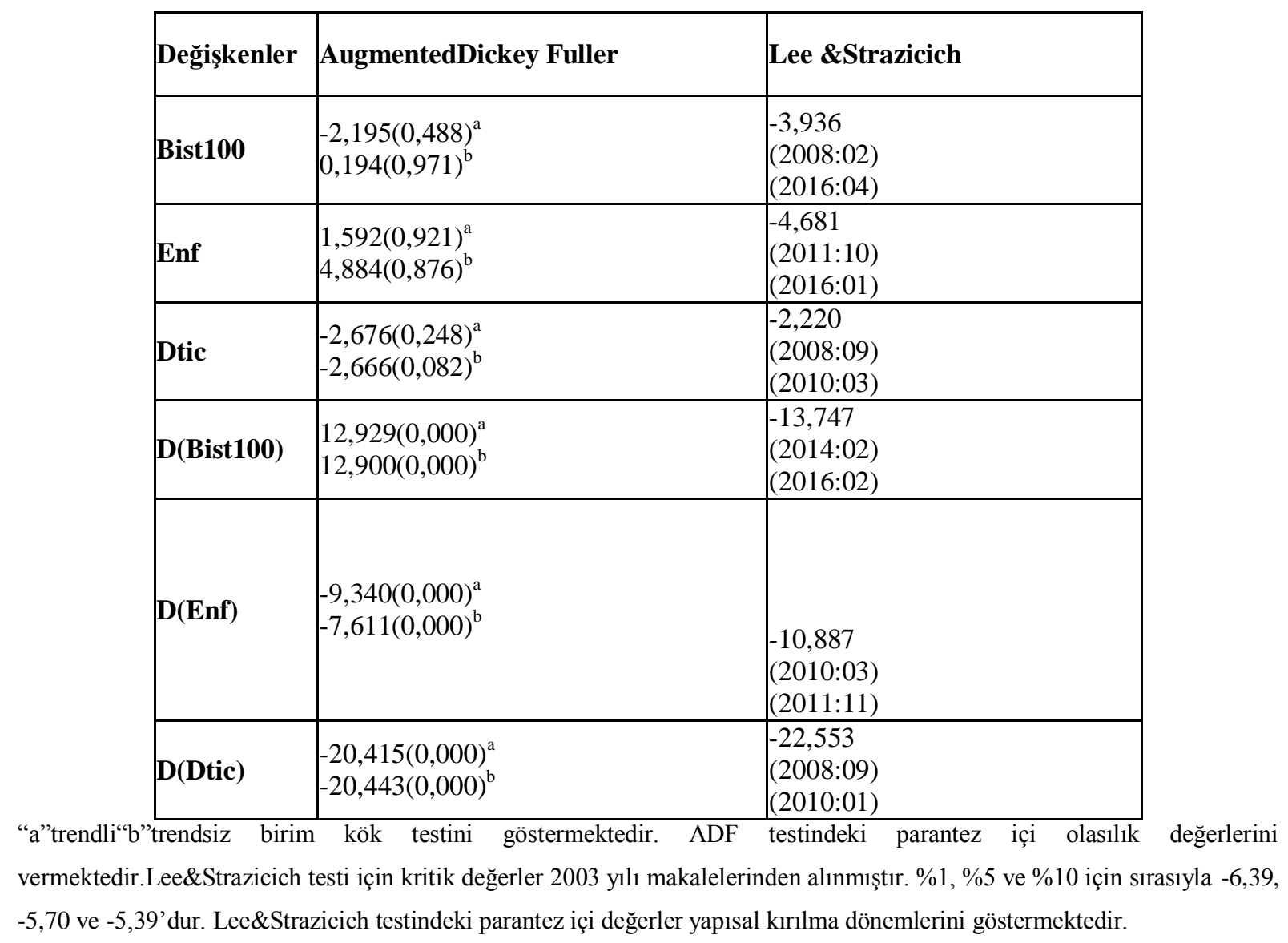

Her iki test istatistiğine göre üç değişken de birinci farkları alındığında 0,05 değerinden küçük olasılık değerlerine sahip olduğundan, $\% 5$ anlamlılık seviyesinde durağan hale gelmiştir. Dolayısıyla bütün değişkenler I(1)'dir.

Daha sonra VAR analizini uygulamak için uygun gecikme uzunluğu bulunmuştur. Gecikme uzunluğu için en sik kullanılan testler Akaike Bilgi Kriterleri (AIK) ile Schwarz Bilgi Kriteri (SC)'dir. Bu testlerin de dahil olduğu gecikme değerlerini gösteren sonuçlar Tablo 2'deki gibidir.

Tablo 2. Gecikme Uzunlukları

\begin{tabular}{lllllllll}
\hline Gecikmeler & 1 & 2 & 3 & 4 & 5 & 6 & 7 & 8 \\
\hline Bilgi Kriterleri & & & & & & & & \\
\cline { 1 - 8 } LR & 1507,58 & 31,245 & 20,359 & 15,877 & 36,934 & 6,828 & $17,704^{*}$ & 11,964 \\
\hline FPE & $1,02 \mathrm{e}+10$ & $9,28 \mathrm{e}+09$ & $9,07 \mathrm{e}+09$ & $9,12 \mathrm{e}+09$ & $7,90 \mathrm{e}+09^{*}$ & $8,43 \mathrm{e}+09$ & $8,32 \mathrm{e}+09$ & $8,54 \mathrm{e}+09$ \\
\hline AIC & 31,556 & 31,464 & 31,441 & 31,445 & $31,301^{*}$ & 31,365 & 31,350 & 31,373 \\
\hline SC & $31,786^{*}$ & 31,868 & 32,017 & 32,195 & 32,224 & 32,461 & 32,618 & 32,815 \\
\hline HQ & 31,649 & $31,628^{*}$ & 31,675 & 31,750 & 31,676 & 31,810 & 31,865 & 31,959 \\
\hline
\end{tabular}

* Kriterin hangi gecikme uzunluğunu kabul ettiğini gösterir. (Her test \%5 anlamlılık seviyesinde değerlendirilmiştir.) 
$\mathrm{Bu}$ çerçevede VAR analizi için uygun gecikme uzunluğu LR kriterine göre 7, FPE ve AIC'ye göre 5 ve Schwarz kriterine göre 1 ve HQ kriterine göre 2'dir. En çok 5 gecikmenin görülmesi (FPE ve AIC)nedeniyle gecikme seviyesi 2 alınmıştır.

Kullanılan değişkenler aynı dereceden entegre olduklarından, bulunan serilerin uzun dönemde ilişkisini açıklayabilmek için hem geleneksel hem de yapısal kırılmaları dikkate alan eşbütünleşme testleri yapılmıştır.

Tablo 3. Johansen Eşbütünleşme Testi Sonuçları

\begin{tabular}{llll}
\hline Iz Testi & \%5 Kritik Değer & Olasılık & Eş Bütünleşme \\
\hline 48,784 & 29,797 & 0,000 & Hiç Yok* \\
\hline 23,535 & 15,494 & 0,0025 & En Çok 1 Tane* \\
\hline 10,457 & 3,841 & 0,0012 & En Çok 2 Tane* \\
\hline Maksimum Özdeğer Testi & \%5 Kritik Değer & Olasıllk & Eş Bütünleşme \\
\hline 25,249 & 21,131 & 0,0124 & Hiç Yok* \\
\hline 13,077 & 14,264 & 0,0763 & En Çok 1 Tane \\
\hline 10,457 & 3,841 & 0,0012 & En Çok 2 Tane*
\end{tabular}

Tablo 3'teki Johansen eşbütünleşme sonuçlarına göre; değişkenler arasında en az bir eşbütünleşme ilişkisi bulunmuştur. $\mathrm{Bu}$ sonuç, kullanılan değişkenler arasında uzun dönemli bir ilişkinin var olduğu anlamına gelir.

Tablo 4'te ise, Gregory\&Hansen yapısal kırılmaları göz önüne alan eşbütünleşme testi sonuçları yer almaktadır. Sonuçlara göre; sabit, trend ve eğimde kırılma içeren regimetrend modeli \% 5 anlamlılık seviyesinde Johansen eşbütünleşme testini desteklemektedir.

Tablo 4. Gregory\&Hansen Eşbütünleşme Testi Sonuçları

\begin{tabular}{|l|l|l|}
\hline & Bist100=f(Dtic, Enf) & Yapısal Kırılma Tarihleri \\
\hline $\begin{array}{l}\text { Constant (Sabit ve seviye kayma kukla değişkeni } \\
\text { içerir) }\end{array}$ & $-4,35$ & $2015: 09$ \\
\hline $\begin{array}{l}\text { Trend(Sabit, trend ve seviye kayma kukla değişkeni } \\
\text { içerir) }\end{array}$ & $-4,33$ & $2015: 09$ \\
\hline Regimetrend (Sabit, trend ve eğimde kırılma içerir) & $-5,54^{*}$ & $2012: 04$ \\
\hline
\end{tabular}

Kritik değerler Gregory\&Hansen (1996: 109) çalışmasından alınmıştır. \%1, \%5 ve \%10 için sırasıyla; -5,77, -5,28 ve 5,02 'dir.

Değişkenler arasında uzun dönemli bir ilişkinin varlığ iki farklı eşbütünleşme testi ile desteklenmiştir. Bu durumda kısa vadede meydana gelen oynaklıkların ne kadar sürede kendi uzun dönem ortalamasına yakınsayacağı HDM ile araştırılabilir. HDM sonuçları Tablo 5'te özetlenmiştir. 
Tablo 5. Normalize Edilmiş Denklem ve Hata Düzeltme Modeli

\begin{tabular}{|c|c|c|c|}
\hline & D(Bist100) & D(Dtic) & D(Enf) \\
\hline $\begin{array}{ll}\text { Hata } & \text { Düzeltm } \\
\text { Katsayısı } & \text { (HDK) }\end{array}$ & $\begin{array}{l}-\mathbf{0 , 0 7 2 2} \\
(0,036) \\
{[-1,992]}\end{array}$ & $\begin{array}{l}-0,00018 \\
(6,6 \mathrm{E}-05) \\
{[2,823]}\end{array}$ & $\begin{array}{l}-2,08 \mathrm{E}-05 \\
(9,7 \mathrm{E}-06) \\
{[-2,142]}\end{array}$ \\
\hline \multicolumn{4}{|c|}{\begin{tabular}{|cc} 
Normalize Edilmis Denklem: \\
Bist100(-1)=-74315 -771,4Enf(-1) & $-553,2$ Dtic $(-1)$ \\
& {$[6,150] \quad[-13,041] \quad[-3,167]$}
\end{tabular}} \\
\hline
\end{tabular}

Not: () içleri standart hataları gösterirken, [] içleri ilgili parametrenin t istatistiklerini göstermektedir.

Hata düzeltme denkleminden elde edilen hata düzeltme katsayısı negatif ve 0 ile -1 arasında değerler almaktadır. Değer bire ne kadar yakınsa uzun dönem dengesi o kadar kısa zamanda yakalanır. Tablo 5'teki hata sonuçlarına göre, düzeltme katsayısı $-0,0722$ bulunmuştur. Hata düzeltme katsayısının \% 5 anlamlılık seviyesinde t tablo değeri 1,96'dır. Sonuç olarak, hata düzeltme katsayısı istatistiki olarak anlamlıdır. Buna göre; BİST 100 Endeksinde kısa zamanda meydana gelen sapmaların her ay yaklaşık 0,0722 kadarı yok olmaktadır. Söz konusu sapmalar $1 /|\mathrm{HDK}|=1 /|-0,0722|=(13,88)$ yaklaşı 14 aylık periyotta uzun dönem dengesine ulaşacaktır.

Normalize edilmiş denklem incelendiğinde, tüm değişkenlerin istatistiki olarak anlamlı parametrelere sahip oldukları görülmektedir. Bu çerçevede, enflasyondaki bir birimlik artış, ele alınan dönemde BİST 100 Endeksinde 771 birimlik bir artışa neden olmaktadır. Dış ticaretteki bir birimlik artışın ise, ortalama olarak BIST 100 Endeksinde 553 birimlik bir artışa neden olacağı görülmektedir. Sonuç olarak, BİST 100 Endeks getirileriyle hem enflasyon hem de dış ticaret açığı arasında uzun dönemli pozitif bir ilişki tespit edilmiştir.

\section{SONUÇ}

Türkiye'deki önemli sermaye piyasası araçlarından biri olan pay senetlerinin, diğer araçlara göre daha riskli olmasına rağmen daha yüksek getiri sağladığı bilinmektedir. Pay senetlerindeki bu riskin minimize edilerek, getirinin artırılması ise, pay senedi fiyatlarının doğru analiz edilmesiyle mümkün olabilmektedir. Pay senedi fiyatları piyasadaki birçok faktörün etkisi altında olduğundan, yatırımcılar açısından pay senetlerine yatırım yapma kararı alınırken, bu faktörlerin tahmin edilmesi oldukça önemlidir. Özellikle hangi faktörün pay senetleri üzerinde daha büyük etkiye sahip olduğu, hangi dönemlerde bu etkinin artış ya da azalış gösterdiği gibi konuların tespit edilmesi, yatırımcıların kararlarının doğru verilmesi bakımından gereklidir.

Bu çalışmada BİST 100 Endeks getirileri ile enflasyon ve dış ticaret açığı arasındaki ilişki, 2004:M1 - 2017:M12 dönemleri arasında aylık veriler kullanılarak incelenmiştir. Çalışmanın verileri; aylık BIST 100 Endeks getirilerinden, aylık enflasyon (TÜFE) rakamlarından ve aylık dış ticaret açığı değişkenlerinden oluşmaktadır. Tüm bu değişkenlerin durağan oldukları birim kök testleri ile tespit edildikten sonra, uzun dönemde ilişkinin varlığını belirlemek üzere Johansen ve Gregory\&Hansen eşbütünleşme testleri yapılmıştır. Yapılan her iki eşbütünleşme analizi sonuçlarına göre; hem enflasyon hem de diş ticaret açı̆̆ 
BİST 100 Endeks getirileriyle uzun dönemde birlikte hareket etmektedir. Diğer bir ifadeyle, BİST 100 Endeks getirileri ile enflasyon ve dış ticaret açığı eşbütünleşiktir. Çalışmada ayrıca, Hata Düzeltme Modeli ile kısa dönemdeki sapmaların ne zaman uzun dönemde dengeye ulaşacağ 1 belirlenmiştir. Modelin sonucuna göre, her ay meydana gelen 0,0722'lik sapma yok olarak, yaklaşık 14 ayda uzun dönem dengesine ulaşacaktır. Başka bir ifadeyle, eğer enflasyon ve dış ticaret açığına ilişkin herhangi bir negatif dalgalanma yaşanırsa, bu durum ancak 14 ay sonra dengeye ulaşabilecektir.

Pay getirilerinin tahmini, yatırımcılar açısından oldukça önemli olduğu için, literatürde pek çok çalışmaya konu olmuştur. Yapılan çalışmalarda pay getirilerini etkileyen çeşitli değişkenler analiz edilmiştir. Enflasyon ve dış ticaret açı̆̆ı değişkenlerinin incelendiği bu çalışmada, BİST 100 Endeks getirileriyle hem enflasyon hem de dış ticaret açığı arasında uzun dönemli pozitif bir ilişki tespit edilmiştir. Bu bulgu literatürde; Choundhry (2001), Engsted ve Tanggaard (2002) (Danimarka için bulunan sonuç hariç), Yılmaz vd. (2004),Hossain (2005), Ratanapacorn ve Sharma (2007), Zügül ve Şahin (2009), Özer vd. (2011), Ray (2012), Ulusan (2014) ve Tiwari vd. (2015) tarafindan yapilan çalışmalarlabenzerlik göstermektedir. Ancak,Khill ve Lee (2000) (Malezya hariç), Li vd. (2010) ve Oxman'ın (2012) yaptığı çalışmalar,pay getirileri ile enflasyon arasındaki ilişkiyi negatif bulmaları bakımından çalışma ile ters düşmektedir.

Dış ticaret değişkeni açısından ise, Yılmaz vd. (2004), Dizdarlar ve Derindere (2008) ve Özer vd. (2011)'nin çalışmalarında ulaşılan endeks ile dış ticaret dengesi arasında negatif bir ilişki olduğu sonucu ve Dizdarlar ve Derindere (2008) tarafından bulunan diş ticaret değişkeninin pay getirilerinden bağımsız olduğu sonucu, bu çalışmada ulaşılan bulgu ile çelişmektedir. Ancak, Ulusan'ın (2014) çalışması, bu çalışmanın sonucunu destekler niteliktedir.

Analizin yapıldığ 1 dönemler itibariyle ulaşılan sonuçlar yorumlanacak olursa; enflasyon rakamlarında görülen artışlar, pay senetlerinin enflasyona karşı yatırımcısını koruyan bir araç olma özelliğinden dolayı, pay senedi getirilerini artırdığı şeklinde yorumlanabilir. Başka bir ifadeyle enflasyon oranlarındaki artış, firmaların varlıklarının değerinin artmasına sebep olmakta ve bu durum pay senetlerinin enflasyona karşı dirençli olması sebebiyle fiyatlarını ve getirilerini artırabilmektedir. Kısacası pay senetleri, sahiplerini enflasyona karşı koruduğu için enflasyonda meydana gelen artışlar, pay senedi fiyatlarını artırmıştır.

Uygulamadaki diğer değişken olan diş ticaret açığı, ülkelerin diş alımları ile dış satımları arasındaki farka göre değişiklik göstermektedir. Türkiye'de özellikle petrol, doğal gaz ve katma değeri yüksek ürün gruplarının dış ticaret açığ 1 verdiği ve BİST 100 Endeksinde yer alan firmaların sadece \%5'lik kısmını bu firmaların oluşturduğu göz önünde bulundurulmalıdır. Bu bağlamda dış ticaret açığı ile pay senedi getirileri arasındaki ilişkinin yönü pozitif olabilmektedir.

Sonuç olarak, makroekonomik değişkenler farklı derecede ve yönde pay getirileriyle etkileşim içindedir. Bu etkileşimde, aradaki ilişkinin doğru bir şekilde belirlenmesi, piyasa yatırımcıları açısından finansal riskin azaltılması için oldukça önemlidir. Ancak, geçmiş çalışmalar incelendiğinde, aynı değişkenlerin farklı zamanlarda pay getirilerini farklı yönlerde etkilediği görülmüştür. Bu nedenle, makroekonomik faktörlerin hangi doğrultuda pay 
getirilerini etkileyeceğiyle ilgili ortak bir görüş söz konusu değildir. Dolayısıyla, analizi yapılan dönemde meydana gelen ekonomik değişme ve gelişmelerin dikkatli bir şekilde irdelenmesi önem arz etmektedir.

Sadece iki makroekonomik değişkenin analize dahil edilmesi, bu çalışma için bir kısıt oluşturmaktadır. Bu sebeple, ileriki çalışmalarda başka faktörler de dahil edilerek analizler genişletilebilir.

\section{KAYNAKLAR}

Aggarwal, R. (1981), "Exchange Rates and Stock Prices: A Study of the U.S. Capital Markets Under Floating Exchange Rates", Akron Business and Economic Review, 12(3), pp. 7-12.

Choudhry, T. (2001), "Inflation and Rates of Return on Stocks: Evidence from High Inflation Countries", Journal of International Financial Markets, (11), pp. 75-96.

Dizdarlar, H.I. - Derindere, S. (2008), "Hisse Senedi Endeksini Etkileyen Faktörler: İMKB 100 Endeksini Etkileyen Makro Ekonomik Göstergeler Üzerine Bir Araştırma", Yönetim, 19(61), ss. 113-124.

Engsted, T. - Tanggaard, C. (2002), "The Relation between Asset Returns and Inflation at Short and Long Horizons", Journal of International Financial Markets, (12), pp. 101118.

Eren, M. (2014), Makroekonomik Faktörler ve Kredi Temerrüt Takaslarının BİST-100 Endeksi Üzerindeki Etkisi. Yüksek Lisans Tezi, Atatürk Üniversitesi Sosyal Bilimler Enstitüsü, Erzurum.

Fisher, I. (1930), “The Theory of Interest”, New York, The Macmillan Company.

Frankel, J.A. (1983), "Monetary and Portfolio-Balance Models of Exchange Rate Determination", Economic Interdependence and Flexible Exchange Rates, (Edited by: Jagdeep Bhandari and Bluford Putnam), Cambridge: MIT Press.

Gregory, A.- Hansen, B. (1996), "Residual Based Tests for Cointegration in Models with Regime Shifts", Journal of Econometrics, 70, pp. 99-126.

Gregory, A. W. - Hansen, B. E., (1996), "Tests for Cointegration in Models with Regime and Trend Shifts", Oxford Bulletin of Economics and Statistics, 58(3), pp. 555-560.

Johansen, S. - Juselius, J. K. (1990), "Maximum Likelihood Estimation and Inference on Cointegration with Applications to Demand for Demand", Oxford Bulletin of Economics and Statistics, 52, pp. 169-210.

Karamustafa, O. - Karakaya, A.(2004), "Enflasyonun Borsa Performans1 Üzerindeki Etkisi’.Kocaeli Üniversitesi Sosyal Bilimler Enstitüsü Dergisi,(7) 1, ss. 23-35. 
Kartal, Ö. (2011), Seçilmiş Makroekonomik Göstergelerin İMKB-100 Endeksine Etkileri. Yüksek Lisans Tezi, İstanbul Üniversitesi Sosyal Bilimler Enstitüsü, İstanbul.

Khil, J. - Lee, B.S. (2000), “Are Common Stocks A Good Hedge Against Inflation? Evidence from the Pacific-Rim Countries”, Pacific-Basin Finance Journal, (8), pp. 457-482.

Kwon, C.S. - Shin, T.S. (1999). "Cointegration and Causality Between Macroeconomic Variables and Stock Market Returns", Global Finance Journal, 10(1), pp. 71-81.

Lee, J. - Strazicich, M. (2003), Minimum LM Unit Root Test with Two Structural Breaks", Review of Economics and Statistics, 85, pp. 1082-1089.

Li, L., Narayan, P. K. ve Zheng, X. (2010), “An Analysis of Inflation and Stock Returns for the UK”,International Financial Markets, Institutions and Money, 20 (2010), pp. 519532 .

Mutan, O.C. - Çanakçı, E. (2007), "Makroekonomik Göstergelerin Hisse Senedi Piyasası Üzerindeki Etkileri”, Sermaye Piyasası Kurulu Araştırma Raporu.

Nawaz, M.- Naeem, M.- Ullah, S. - Khan, S.U. (2017), “Correlation and Causality between Inflation and Selected Macroeconomic Variables: Empirical Evidence from Pakistan (1990-2012)", iBusiness, 9, pp. 149-166.

Oxman, J. (2012), "Price Inflation and Stock Returns”. Economics Letters, 116, pp. 385-388.

Ozlen, Ş. - Ergun, U. (2012), "Macroeconomic Factors and Stock Returns", International Journal of Academic Research in Business and Social Sciences, 2(9), pp. 315-343.

Özer, A.- Kaya, A. - Özer, N. (2011). "Hisse Senedi Fiyatları ile Makroekonomik Değişkenlerin Etkileşimi”. Dokuz Eylül Üniversitesi İktisadi ve İdari Bilimler Fakültesi Dergisi, 26(1), ss. 163-182.

Ratanapacorn, O. - Sharma, S. C. (2007), "Dynamic Analysis Between the US Stock Returns and the Macroeconomic Variables", Applied Financial Economics, 17(5), pp. 369-377.

Ray, S. (2012), “Testing Granger Causal Relationship between Macroeconomic Variables and Stock Price Behaviour: Evidence from India", Advances in Applied Economics and Finance, 3(1), pp. 470-481.

Tiwari, A.K.- Dar, A.B.- Bhanja, N.- Arouri, M. - Teulon, F. (2015), "Stock Returns and Inflation in Pakistan”. Economic Modelling, 47 (2015), pp. 23-31.

Ulaş, S. (2010), Enflasyon ve Döviz Kurunun Hisse Senedi Piyasası'na Etkileri, İMKB'de Uygulaması, Yüksek Lisans Tezi, Selçuk Üniversitesi Sosyal Bilimler Enstitüsü, Konya.

Ulusan, M. (2014). "BIST-100 Getirileri, D1ş Ticaret Açığı ve Enflasyon Büyümesinin Nedensellik Açısından Analizi”,1. Üretim Ekonomileri Kongresi Bildiri Kitabı, İstanbul. 
Umutlu, G., Ertürk, M. - Sezer, Y. (2010), “IMMKB 100 Endeksini Etkileyen Faktörler”,Mali Ufuklar Dergisi, Ocak, ss. 7-17.

Uzun, U. - Güngör, B. (2017), "Borsa Endeksleri ile Ülkelerin Seçilmiş Makroekonomik Göstergeleri Arasındaki İlişkinin Uluslararası Boyutta İncelenmesi”, AİBÜ Sosyal Bilimler Enstitüsü Dergisi, 17(4), ss. 1-30.

Tangjitprom, N. (2012), "The Review of Macroeconomic Factors and Stock Returns", International Business Research, 5(8), pp. 107-115.

Yeşildağ, E. (2016), “Makroekonomik Faktörlerin Borsa İstanbul'daki Endeks Getirilerine Etkisinin Arbitraj Fiyatlama Modeli ile Analizi", Süleyman Demirel Üniversitesi Sosyal Bilimler Enstitüsü Dergisi, CİEP Özel Sayısı, ss. 51-76.

Yılmaz, Ö.- Güngör, B. - Kaya, V. (2004), "Hisse Senedi Fiyatları ve Makro Ekonomik Değişkenler Arasındaki Eşbütünleşme ve Nedensellik”, İMKB Dergisi, 8(34), ss. 116.

Zengin, N. (2009). Seçilmiş Makroekonomik Göstergeler ile İMKB-100 Endeksi Arasındaki İlişkinin Analizi, Yüksek Lisans Tezi, Marmara Üniversitesi Bankacılık ve Sigortacılık Enstitüsü, İstanbul.

Zügül, M. - Şahin C. (2009), "İMKB 100 Endeksi ile Bazı Makroekonomik Değişkenler Arasındaki İlişkiyi İncelemeye Yönelik Bir Uygulama”, Akademik Bakış Dergisi, 16, Nisan, ss. 1-16. 